\title{
Mardin Büyükşehir Belediyesi Örneğinde Yeni Büyükşehir Belediye Modeli Uygulamasının Yerel Halka Yansımaları
}

\author{
DOI: $10.26466 /$ opus. 823674
}

*

\author{
Muzaffer Bimay * \\ *Öğr. Gör. Dr., Batman Üniversitesi \\ E-Posta: muzafferbimay@gmail.com \\ ORCID: 0000-0002-6742-2852 \\ Öz
}

Günümüzde her geçen gün büyüyen kentlerin artan sorunları ve çeşitlenen ihtiyaçlarının karşılanması için yeni yerel yönetim modellerine veya var olanların revize edilmesine ihtiyaç duyulmaktadır. Türkiye'de 1980'lerden sonra yasal ve anayasal bir zırha bürünen büyükşehir modeli 2012 yılında çıkarılan 6360 sayılı Kanun ile yeniden reforme edilmiş, ancak Kanun'un içerik ve uygulamasından kaynaklı ortaya çıkan tartışmalar günümüze kadar devam etmiştir. İşte bu çalışma, 2012 yılında çıkarılan 6360 sayılı Kanun ile büyükşehir statüsüne kavuşan Mardin'de, söz konusu Kanun'un yerel halka olan yansımaların yapılan tartışmalar bağlamında ortaya koymayı amaçlamıştır. Bu çerçevede Mardin'de yaşayan yerel halkın arada geçen sekiz yıllık zaman diliminde büyükşehir yerel yönetim modeline ilişkin yaklaşımları ve algıları irdelenmiştir. Bu bağlamda yapılan çalışma için nicel araştırma yöntemi benimsenmiş, teorik arka plandan sonra bulgularm betimsel veya tanımlayıcı istatistikleri yapilarak yorumlanmıştır. Elde edilen verilerden yola çıkarak katılımcıların yeni büyükşehir modeline olumlu yaklaştıkları, ancak yetki, denetim, temsil ve katılım gibi birçok açıdan bu modeli yetersiz gördükleri söylenebilir. Ayrıca katılımcıların yeni büyükşsehir modeline karşı olan tutumları ile demografik değiş̧enler arasında da istatiksel olarak anlaml farklılıklar ortaya çıkmıştır. Dolayısıyla 6360 sayılı Kanun eskiye göre daha iyi gelişmeler ortaya koymuş olsa da özellikle uygulamada, merkez-yerel ilişkileri ile demokratik temsil ve katılım açısından beklentileri karşılamadığı ve bu yüzden Kanun'un yeniden reforme edilmesi gerektiğgi belirtilmiştir.

Anahtar Kelimeler: Yeni Büyükşehir Modeli, 6360 sayılı Kanun, Reform, Mardin 


\title{
Reflections of the New Metropolitan Municipality Model Application to Local People in the Example of Mardin Metropolitan Municipality
}

\begin{abstract}
Today, new local administration models or revision of existing ones are needed in order to meet the increasing problems and diverse needs of the growing cities. After the 1980s in Turkey, which assumes a legal and constitutional armor metropolitan model with Law No. 6360 issued in 2012 it has been rereformed, however, the discussions arising from the content and implementation of the Law have continued until today. This study aims to reveal the reflections of the Law in question on the local people in the context of the discussions in Mardin, which gained metropolitan status with Law No. 6360 enacted in 2012. In this framework, the approaches and perceptions of the local people living in Mardin regarding the metropolitan local administration model in the intervening period of eight years were examined In this context, the mixed research method was adopted for the study conducted, and after the theoretical background, the findings were interpreted by making descriptive and other statistical analyzes. Based on the data obtained, it can be said that the participants approach the new metropolitan model positively, but see this model inadequate in many aspects such as authority, supervision, representation and participation In addition, statistically significant differences have emerged between the attitudes of the participants towards the new metropolitan model and demographic variables.Therefore, although the Law No. 6360 showed better developments than the past, it was stated that especially in practice, it did not meet the expectations in terms of center-local relations and democratic representation and participation, and therefore the Law should be reformed again.
\end{abstract}

Keywords: New Metropolitan Model, Law No. 6360, Reform, Mardin 


\section{Giriş}

Demokrasinin vazgeçilmez unsuru olan yereldeki yönetimlerin yetki ve sorumluluk açısından nasıl bir yönetim şekli alacağı, demokratiklik derecelerinin sınırının ne olacağı son iki yüzyılın en önemli tartışmalarından biri olarak karşımıza çıkmışır. Bu dönemde sanayileşme ve kentlerin çekici özelliklerine bağlı olarak sürekli artan göçler ve bu göçlerin meydana getirdiği demografik baskılar nedeniyle genişlemeye başlayan kentlerde, bir yandan merkezde bulunan kentin yerlileri, diğer taraftan kentin çeperlerinde yoğunlaşan marjinal grupların meydana getirdiği ikili bir yapı ortaya çıkmıştır. Bu ikili yapı içerisinde ayrışan nüfusun ihtiyaç duyduğu kamu hizmetlerini ve siyasal katılımı sağlamak, yönetsel ve mali açıdan gittikçe zorlaştığı görülmüştür (DeHoog, Lowery ve Lyons, 1991, s. 479-480; MacLeod ve Jones, 2011, s. 2453).

Birleşmiş Milletler Ekonomik ve Sosyal İşler Dairesi'nin verilerine göre 1800 yılında dünya nüfusunun yaklaşık \% 3'ü kentlerde yaşarken, bu oran 1900 'de \% 14'e, 1950'de \% 30'a, 2018 yılında \% 55'e yükselmiştir. Bu oranın 2050 yilında \% 68'e (Davis, 1965, s. 45; Onyango, 2018, s.49) ve mega kent sayısının 2030 yılına kadar 43'e çıkacağı öngörülmektedir (Department of Economic And Social Affairs [UN DESA], 2018). Türkiye'de ise 1950 yılında \% 18,5 olan kentsel nüfus, (Tortop, Aykaç, Yayman ve Özer, 2014, s. 216-217), 2012 'de \% 77,3'e ve günümüzde ise yaklaş1k \% 92,8'e çıkmıştır (Türkiye İstatistik Kurumu [TÜİK], 2020). Dolayısıyla her geçen gün daha da büyüyen büyük kentlerin artan sorunlarının eski tip kentsel yönetim modelleriyle çözülemeyeceği anlaşılmıştır. Bu nedenle dünyada ve ülkemizde, özellikle 1980'lerden itibaren kamu yönetiminde ortaya çıan yeni anlayışların da etkisiyle, yerelleşme ve yönetişim uygulamalarını da ön plana çıkartan birleştirme dahil birçok kent modeli ortaya atılmış ve gerekli mevzuat değişiklilerine gidilmiştir (Zimmermann, 2007, s.1-3; Rydergard, 2012, s.7-8; Bowornwathana ve Poocharoen, 2005, s. 234; Lefevre, 1998, s.9; Keleş, 1985, s. 70-71; Güler, 1987, s. 117). Böylece 1850'lerden beri reformcuların ve 1950'lerden beri çağdaş akademisyenlerin gündeminde olan büyükşehirlerle ilgili tartışmalar aşamalı bir şekilde belli bir kalıba oturtulmaya çalışılmıştır (Visser, 2002, s. 40).

İşte böyle bir arka plan içerisinde ülkemizde, 1970'lerden itibaren büyükşehirlerin nasıl yönetilmesi gerektiğine ilişkin arayışlar başlamış ve 1984 ile 
2012 yılları arasında kuruluş (dar ölçek), genişletme ve bütünleştirme (alansal) şeklinde aşamalı bir süreç izlenilmiştir (Arıkboğa, 2013, s. 1). Bu bağlamda 2012 yılında yürürlüğe giren ve 2014 yılında fiili olarak uygulamaya konulan 6360 sayılı Kanun, yerelleşme ve yönetişim bağlamında devrim niteliğinde değişiklikler ortaya koymuş, ancak içerik ve uygulamadan kaynaklı birçok tartışma ve eleştiriyi de beraberinde getirmiştir. Buradan hareketle bu çalışma, 1867 yılından beri bir yerel yönetim birimi olarak varlığını sürdüren ve 2012 yılında çıarılan 6360 sayılı Kanun ile büyükş̧ehir statüsüne kavuşan Mardin'de, aradan geçen sekiz yıllık zaman diliminde söz konusu Kanun'un uygulamadaki yansımalarını yerel halkın tutumları üzerinden ela almayı amaçlamıştır. Dolayısıyla ele aldığım temel soru, 2012 yılından beri uygulanan büyükşehir modelinin yerel halk üzerindeki etkilerinin neler olduğudur. Çalışmanın problemi bağlamında ortaya çıkan ana beklenti, "6360 sayılı Kanun'un, yürürlüğe girmesinden itibaren geçen sürede, yerel halka etkilerinin olumlu olduğu ve yerel halkın yaşamında önemli değişmelere yol açtığı" şeklindedir. Bu çalışma ile, büyükşehir modeline geçişle birlikte Mardin'de ortaya çıkan değişimin yukarıda tespit edilen ana beklentiyi doğruladığı, ancak demokratik temsil ve katılımı sağlama bakımından Kanun'un gerek içeriği ve gerekse uygulamasında merkez-yerel ilişkilerinin arzu edilen seviyeye ulaşamadığı söylenebilir. Belirli bir zaman diliminde 6360 sayılı Kanun'un uygulamadaki yansımalarının ortaya çıkarılması ile gerek uygulamaya ve gerekse literatüre önemli katkı sağlaması ve önümüzdeki dönemlerde ortaya çıkması beklenilen yeni model tartışmalarına da katkı sunması hedeflenmektedir.

\section{Büyük Kentler İçin Yeni Yönetim Arayışlarının Arka Planı}

Kentlerin ortaya çıkışı ve siyasi otoritelerin kurulması M.Ö. 3000 yıllara dayanmasına rağmen (Mumford, 2007, s. 49; Huot, Thalmann ve Valbelle 2000, s. 28), büyükşehir yönetimlerinin ortaya çıkışı 18. yüzyıldan itibaren endüstriyel bölgelerin kentlerin etrafında yoğunlaşması ve kentlerin genişlemeye başlamasıyla gerçekleşmiştir (Sjoberg, 2002, s.41). İlk örnekleri ABD (Newyork)'de ortaya çıkan büyükşehir modeli, daha sonra Tokyo (1888), Londra (1899), Paris (1899) ve Toronto (1954)'da karşımıza çıkmakta ve günümüzde iki kademeli anakent federasyonu şeklinde uygulamaları devam etmektedir (Frey ve Zimmer, 2001, s. 25-28; Eke, 1982, s.51; Kavruk, 2002, 
s.180; Ökmen ve Parlak, 2015, s.92). Ülkemizde ise ilk tartısmalar, yerel ve bölgesel oluşumların başlandığı Osmanlıya dayanmaktadır. İstanbul özelinde kentlerin büyümesi ve ihtiyaçlarının mevcut yerel yönetimler aracıllğıyla gerçekleştirilemeyeceğinin anlaşılması üzerine, 1857 ve 1869 tarihli ç1karılan nizamnamelerle "bölme" yöntemi tercih edilerek iki kademeli federal bir yapıya geçilmiştir (Keleş, 1985, s.73).

Cumhuriyet dönemine kadar nizamnamelerle dizayn edilen büyükşehirlerle ilgili 1924 yılında çıkarılan 442 sayılı Köy Kanunu'n gerekçesinde yeniden düzenleme yapılması öngörülmüş (Özgür, 2007, s. 111; Çınar, Çiner ve Zengin, 2009, s. 40) ve sonrasında Ankara ve İstanbul için 1956'ya kadar süren farklı bir yönetim modeli getirilmiştir (Al, 1996, s.23; Keleş, 1998, s.272-273). 1961 Anayasa'sinda hiç sözü edilmeyen, 1970 ve hatta 1980'lere kadar sadece hükümet programlarında ve kalkınma planlarında gerekliliği ortaya konulan büyükşehir modeli ile ilgili ilk ciddi adımlar 1980'lerden sonra ortaya çıkmıştır. Bu dönemde küreselleşme ve neo-liberal siyasi yapılanmanın kamu yönetiminde yarattığ1 dönüşümlerden büyük kentlerde etkilenmiş ve büyükşehir alan ölçeğinde ortaya çıkan birçok sorunun çözümü için yönetişime dayanan yeni arayışlar içine girilmiştir (DeHoog ve diğerleri, 1991; Lyons ve Lowery, 1989; Wood, 1958).

12 Eylül 1980 Askeri Müdahale sonrası Milli Güvenlik Konseyi'nin (MGK) 34 sayılı Kararı ve bu Kararın daha ayrıntılı ifadesi olan 1981 tarihli “2561 sayılı Büyükşehirlerin Yakın Çevresindeki Yerleşim Yerlerinin Ana Belediyelere Bağlanması Hakkında Kanun" ile nüfusu 300.000'i aşan büyükşehirlere çevresindeki ilçe ve köylerin birleştirilmesi kriteri getirilmiştir (Tortop vd., 2014, s. 215; Keleş, 1998, s. 275). Böylece yapılan bu düzenlemelerle, bazılarının tüzel kişiliği sonradan geri verilmesine rağmen birçok belediye ve köyün tüzel kişiliği kaldırılmıştır (Keleş, 1985, s. 75-76; Güler, 1987, s. 131-133). Daha sonra büyükşehir yönetim modeli, 1982 Anayasası'nın 127. maddesinde “büyük yerleşim yerleri için özel yönetim biçimleri getirilebilir" hükmü ile ilk defa anayasal bir çerçeveye alınmıştır. Bunun hemen ardından, 1984 yılında, İstanbul, Ankara ve İzmir'de büyükşehir belediyelerinin kuruluş ve yönetimini düzenleyen ve iki kademeli büyükşehir belediyeciliğine geçişi öngören 195 sayılı KHK, aynı yıl çıkartılan 3030 sayılı Büyükşehir Belediyesi Kanunu ve 3194 sayılı İmar Kanunu ile büyükşehir sistemi kurumsal ve hukuksal temele oturtulmaya çalışılmıştır (Keleş, 1985, s. 77; Yaşamış, 1995, s. 94; Güler, 1987, s. 142; İspir, 1982, s. 141). 
2000 'li yıllardan sonra iç ve dış dinamikler tarafından tetiklenen reformların etkisi (Emini, 2009, s. 35) ve 2004 yılında TBMM tarafından kabul edilen, ancak dönemin Cumhurbaşkanı tarafından iade edilen Kamu Yönetiminin Temel İlkeleri ve Yeniden Yapılandırılması Hakkında Kanun Tasarısının yasalaşmamasının ortaya çıkardığı boşluğu doldurmak amacıyla 2004 yılında 5216 sayılı Büyükşehir Belediyesi Kanunu çıkarılmıştır. Bu Kanun ile büyükşehirler için hem ölçek hem de 750 bin nüfus kriteri getirilmiştir. Ayrıca İstanbul ve Kocaeli illerinde büyükşehir belediye sınırları il mülki sınırları olarak belirlenmiştir (Çolak, Sağlam ve Topal, 2017, s. 8). Yine bu Kanun'un tamamlayıcısı olarak 06.03.2008 tarih ve "5747 sayılı Büyükşehir Belediyesi S1nırları İçerisinde İlçe Kurulması ve Bazı Kanunlarda Değişiklik Yapılması Hakkında Kanunu" ile büyükşehir kurulan yerlerde alt kademe belediyesi olarak sadece ilçe belediyesi statüsüne yer verilmiş ve nüfus kriterine bağl1 olarak belde belediyeleri de kaldırılmıştır (Koçak ve Ekşi, 2010, s. 303-304). Böylece büyükşehirlere ilişkin düzenlemeler 2004'e kadar dar bir ölçekle yapılmış, 2004-2008 yılları arasında genişlemeye dayalı "bütünşehir" modeli benimsenmiştir (Arıkboğa, 2013, s. 53-54).

\section{Sayılı Kanun Ve Bu Kanuna Getirilen Eleştiriler}

Kamu yönetiminde etkinlik ve verimliliği artırmak, temsil ve katılımı sağlamak, yönetsel kapasite ve koordinasyon eksikliğinden kaynaklanan sorunları gidermek, daha bütüncül ve bölgesel çapta planlar yapmak amacıyla çıkar1lan 6360 sayılı Kanun, 12/11/2012 tarihinde kabul edilmiş ve 30 Mart 2014 yerel seçimleri sonrası uygulanmak üzere 06/12/2012 tarihinde 28489 sayılı Resmi Gazete'de yayımlanmıştır. Başlangıçta Aydın, Balıkesir, Denizli, Hatay, Malatya, Manisa, Kahramanmaraş, Mardin, Muğla, Tekirdağ, Trabzon, Şanlıurfa ve Van illerini kapsayan Kanun, 14/03/2013 tarihinde çıkarılan 6447 sayılı Kanun ile Ordu ili de dahil edilerek kanunun adı “On Dört İlde Büyükşehir Belediyesi ve Yirmi Yedi İlçe Kurulması ile Bazı Kanun Hükmünde Kararnamelerde Değişiklik Yapılmasına Dair Kanun" şeklinde genişletilmiştir. Böylece Türkiye'deki büyükşehir belediye sayısı 30'a yükselmiş ve bununla Türkiye coğrafi alanının \% 50'si, nüfusun \% 76'sı büyük şehir belediyesi s1nırlarına dâhil edilirken Türkiye geneli kentleşme oranı da \% 90'lara yükselmiştir. 6360 sayılı Kanun ile getirilen düzenlemeler sistematik bir şekilde şu şekilde özetlenebilir (Parlak, 2013; Arıkboğa, 2013, Tortop vd., 2014; Kaypak 
ve Yılmaz, 2016; Apan, 2016; Bingöl, Yazıcı ve Akın., 2013; Genç, 2014; Ad1güzel, 2018; Çalcalı, 2014; Ünal ve Tanrıvermiş, 2018; Gözler, 2013):

- Büyükşsehir belediyelerinin sınırları, il mülki sınırları haline getirilmiştir. Buna bağlı olarak bu illere bağlı ilçelerin mülki sınırları içindeki köy (orman köyleri dahil) ve belde belediyelerinin tüzel kişiliğine son verilmiş, köyler mahalleye, belediyeler ise tek mahalle olarak bağlı bulundukları ilçenin belediyesine katılmıştır. Büyükşehir belediyelerinde yeni bir ilçe belediyesinin kurulabilmesi için daha önce en az 50.000 olan nüfus kriteri 20.000'e çekilmiştir.

- Büyükşehir olan illerde bucak teşkilatları ile il özel idarelerinin tüzel kişiliği kaldırılmış ve "köylere hizmet götürme birlikleri" tasfiye edilmiştir.

- Yeni mahalle kurulması için 5 yıllık bir geçiş dönemi ve en az 500 nüfus kriteri getirilmiştir.

- Büyükşehir belediyesi olabilmek için 5216 sayılı Kanunda yer alan 750.000 nüfus şartının, il mülki sınırlar dahilinde genişletilmesi şartı getirilmiş ve bu şartı sağlayan illerin büyükşehir olması sağlanmıştır.

- Encümen üye sayısı 11'den 7'ye düşürülmüş ve genel sekreter, encümenin doğal üyesi yapılmıştır. Valiler tarafından il genel meclisi toplantılarına sunulan önerilerin ilk toplantıda ela alınması zorunlu hale gelmiştir.

- Büyükşehir olan 30 ilde, mülki idareye bağlı olarak yatırım izleme ve koordinasyon başkanlığı, ulaşım koordinasyon merkezleri ve tüm illeri kapsamak üzere 112 acil yardım merkezleri kurulmuştur.

- Büyükşehir belediyeleri ve büyükşehir ilçe belediyelerinin merkezi bütçeden aldıkları paylar büyükşehir ilçe belediyeleri için \%2,50'den $\% 4,50$ 'ye, büyükşehir belediyeleri için \% 5'ten \% 6'ya çıkarılmıştır.

- Büyükşehir ve ilçe belediyeleri; meclisin alacağı kararlarla mabetlere indirimli bedelle ya da ücretsiz olarak içme ve kullanma suyu verebilme, sağlık, eğitim, kültür tesis ve binalarının yanı sıra mabetlerin de yapım, bakım ve onarımını yapabilme; yurtiçi ve yurtdışı müsabakalarda üstün başarı gösteren veya derece alan sporcuların yanı sıra teknik yönetici, antrenör ve öğrencilere ödül verebilme, amatör spor kulüplerine nakdi yardım yapma yetkisi verilmiştir. Yine büyükşehir belediyelerine, terminal ve otopark, mezarlık, hal, mezbaha, temizlik hizmetleri, adres ve numaralandırma hizmetlerini meclis kararı ile ilçe belediyelerine devretme ya da bu hizmetleri birlikte yapma yetkisi verilmiştir. 
- Büyükşehir belediyelerine ve nüfusu 100.000 üzerinde olan ilçe belediyelerine kadınlar ve çocukların barınabilecekleri konukevleri açma zorunluluğu getirilmiştir.

6360 sayılı Kanun, yukarıda ifade edilen amaç ve gerekçeler doğrultusunda hayata geçirilmeye çalışılmış olsa da uygulamada başta yetki ve hizmetin dağıtımı olmak üzere temsil, katılım, kaynak, denetim ve koordinasyon gibi birçok konuda tartışma konusu olmuştur (Bulut ve Dönmez, 2019, s. 29). Genel olarak il özel idareleri, belde belediyeleri ve köylerin tüzel kişiliklerinin kaldırılmasının Anayasa'nın 127. maddesine aykırı olduğu ifade edilmiştir (Gözler, 2013, s. 40). Ayrıca Kanun'un hazırlanmasında bilimsel bir hesap yapılmadığı, yerel toplulukların görüşlerine yeteri kadar başvurulmadığı, belediye encümeninde atanmışların olması nedeniyle katılım olanaklarının ortadan kaldırıldığı ve bu nedenle temsil ve katılım açısından ortaya çıkan demokratik meşruiyet eksikliğinin Avrupa Konseyi Yerel Yönetimler Özerklik Şartına ve Mevzuat Hazırlama Usul ve Esasları Yönetmeliği'ne aykırı olduğu belirtilmiştir (Çukurcayır, 2012, s. 20; Çelik ve Altıparmak, 2013, s. 31; Gözler, 2013, s. 1-2; Adıgüzel, 2018, s. 14). Diğer taraftan 750.000 nüfus şartının il mülki sınırları olarak genişletilmesinin kentler açısından adaletsiz bir durum ortaya çıkartacağı, özellikle köylerin mahalleye dönüşmesinden kaynaklanan fiziki uzaklığın hizmeti ve denetimi aksatacağı için maliyeti arttıracağı ve bununda yerelleşme ve "subsidiarity (hizmette halka yakınlık)" ilkelerine aykırılık teşkil ettiği belirtilmiştir (Parlak, 2013: 1). Yatırım İzleme ve Koordinasyon Başkanlığı (YİKOB) ile oluşan vesayet, Kanun'un uygulanmasını bıraktığı pek çok konuyu düzenleyen yönetmeliğin İçişleri Bakanlığı'nca çıarılması, gelirle ilgili bazı düzenlemelerin Bakanlar Kurulu'na bırakılması, planlama ve koordinasyonun tek elden yürütülmesi gibi birçok düzenlemenin merkeziyetçiliği arttıracağı ileri sürülmüştür (Görmez, 1993, s. 23).

\section{Yöntem}

Bu araştırma için geliştirilen yöntem, nicel araştırma yöntemidir. Bu yöntem, değişkenlerin ölçümlerinin sayıyla ifade edilmesini sağlayan kantitatif ölçümlere dayanmaktadır (Punch, 2011). Araştırma modeli olarak betimsel veya tanımlayıcı araştırma modelinden yararlanılmıştır. Bu tür araştırmalarda önemli olan mevcut durumu betimlemektir. Dolayısıyla araştırmacı, 
bağımsız değişkenler üzerinde herhangi bir şekilde oynama yapmaz (Can, 2017:12). Verilerin toplama yöntemi ve aracı olarak anket tekniği tercih edilmiş ve kapalı uçlu sorulardan oluşan bir anket hazırlanmıştır. Bu yöntemle, verilerin elde edileceği kişilerin, doğrudan okuyarak cevaplandıracakları bir soru listesi aracılı̆̆ıyla verilerin elde edilmesi amaçlanmıştır. Anket formu hazırlanırken bu konu ilgili olarak yapılmış birçok uygulamalı bilimsel çalışmadan da yararlanılmıştır. Anket, çoktan seçmeli ve beşli likert ölçekli sorulardan oluşmakta ve beşli likert ölçek, "kesinlikle katılmıyorum, katılmıyorum, orta düzeyde katılıyorum, katılıyorum ve kesinlikle katılıyorum" seçeneklerini kapsamaktadır.

Anketler, Batman Üniversitesi'nin 07.07.2020 tarihli ve 2020/03 sayılı Etik Kurulu Kararı ile 2020 yılının Haziran-Ağustos ayları arasında gerçekleştirilmiştir. Bu süre içinde Mardin Büyükşehir Belediyesi sınırları içinde yaşayan ve araştırma evrenini oluşturan kişiler içinden anket yapmayı kabul eden 18 yaşından büyük toplam 364 kişi ile yüz yüze görüşme yapılmıştır. Araştırmanın kapsamı, kaynak ve sürenin kısıtllı̆̆̆ nedeniyle Mardin Büyükşehir Belediyesi ile sinırlı tutulmuştur. Anket yoluyla elde verilerin betimsel istatistikleri SPSS 24 programı aracılığıyla yapılmıştır. Böylece araştırmada memnuniyet düzeylerini ölçmek amacıyla tanımsal istatistik ölçülerinden aritmetik ortalama ve oransal frekanslardan yararlanılmıştır. Veri toplama aracının güvenirlik çalışmaları için öncelikle faktör analizi yapılmış ve elde edilen veriler aşağıdaki tabloda gösterilmiştir.

Tablo 1. 6360 Sayılı Kanun'un Yansımaları Ölçeğine Ait Faktör ve Güvenirlik Analizi Sonuçları

İfadeler
Büyükşehir Belediyesine geçiş sonrası Büyükşehir Belediyesi il mülki sınırlarına kadar,527
yeterli düzeyde hizmet götürmektedir.
Büyükşehir Belediyesine geçiş sonrası su ve kanalizasyon gibi alt yapı yatırım ve hiz-,583
metlerinde iyileşme olduğunu düşünüyorum.
Büyükşehir Belediyesine geçiş sonrası kentimde katılımcı, şeffaf bir yönetim anlayışı,614
benimsenmiştir.
Büyükşehir Belediyesine (BŞBY) geçiş sonrası yaşadığım kentte yol bakım ve onarım,761
faaliyetlerinin arttı̆̆ını düşünüyorum.
Büyükşehir Belediyesine geçiş sonrası yaşadığım kentin kırsal kesimlerinde yol, su ve,683
kanalizasyon faaliyetlerine yönelik yatırım, bakım ve onarım hizmetleri arttı.




\begin{tabular}{|c|c|c|c|}
\hline \multicolumn{4}{|l|}{$\begin{array}{l}\text { Büyükşsehir Belediyesine geçiş sonrası yaşadığım kentin kırsal kesimlerinde yaşayan,643 } \\
\text { insanların yaşam kalitesinde artış olduğunu düşünüyorum. }\end{array}$} \\
\hline \multicolumn{4}{|l|}{$\begin{array}{l}\text { Büyükş̧ehir Belediyesine geçiş sonrası yaşadığım kentin çevre ve peyzaj düzenlemele-,629 } \\
\text { rinde olumlu gelişmeler olduğunu düşünüyorum. }\end{array}$} \\
\hline \multicolumn{4}{|l|}{$\begin{array}{l}\text { Büyükşehir Belediyesine geçiş sonrası yaşadığım kentteki ulaşım hizmetlerinde iyi-,665 } \\
\text { leşme olduğunu düşünüyorum. }\end{array}$} \\
\hline Büyükşehir Belediyesine geçiş sonrası otopark ücretleri arttı & 478 & & \\
\hline Büyükşehir Belediyesine geçiş sonrası toplu taşıma ücretlerinde artış yaşandı. & 676 & & \\
\hline Büyükşehir Belediyesine geçiş sonrası konut satış ve kira fiyatları arttı. & 761 & & \\
\hline Büyükşehir Belediyesine geçiş sonrası çevre temizlik ve emlak vergileri arttı. & 820 & & \\
\hline Büyükşehir Belediyesine geçiş sonrası su faturalarında artış yaşandı. & 835 & & \\
\hline Büyükşehir Belediyesine geçiş sonrası kütüphane hizmetlerinde artış yaşandı. & ,552 & & \\
\hline $\begin{array}{l}\text { Büyükş̧ehir Belediyesine geçiş sonrası kentimin tarihi ve kültürel bakımdan önem } \\
\text { taşıyan mekanların, bakım onarım ve korunmasına yönelik hizmetler arttı. }\end{array}$ & ,555 & & \\
\hline Büyükşehir Belediyesine geçiş sonrası yaşadığım kentin trafik sorunları arttı. & & 468 & \\
\hline $\begin{array}{l}\text { Büyükşehir Belediyesi ile ilçe belediyelerinin birbirleri ile uyum içerisinde çalıştığını } \\
\text { düşünüyorum. }\end{array}$ & & 761 & \\
\hline Büyükşehir Belediyesine geçiş sonrası yaşadığım kentteki iş olanakları arttı. & & 675 & \\
\hline Büyükşehir Belediyesine geçiş sonrası sosyal ve sportif faaliyetler arttı. & & 675 & \\
\hline $\begin{array}{l}\text { Büyükşehir Belediyesine geçiş sonrası sanayi ve tıbbi atıkları bertaraf etmeküzere yeni } \\
\text { atık istasyonları yapıldı. }\end{array}$ & & 682 & \\
\hline $\begin{array}{l}\text { Büyükşehir Belediyesine geçiş sonrası çevre ve hava kirliliğine yönelik yeteri kadar } \\
\text { önlemler alınmaktadır. }\end{array}$ & & ,521 & \\
\hline 6360 sayılı Kanun sonrası İl Özel İdarelerinin kapatılmasından memnunum. & & & 725 \\
\hline 6360 sayılı Kanun sonrası Belde Belediyelerinin kapatılmasından memnunum. & & & 752 \\
\hline $\begin{array}{l}6360 \text { sayılı Kanun sonrası köylerin tüzel kişiliğinin kaldırılarak mahalleye dönüştürül- } \\
\text { mesinden memnunum. }\end{array}$ & & & 762 \\
\hline 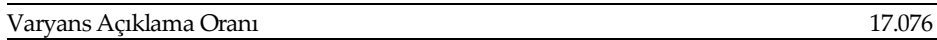 & 14.834 & 13.291 & 10.986 \\
\hline Toplam Varyans Açılama Oranı & & & 56.187 \\
\hline Ortalama & 3,541 & 3,353 & 3,215 \\
\hline Standart Sapma & 645 & 691 & ,740 \\
\hline Cronbach's Alpha (Genel) & & & 0,829 \\
\hline Kaiser-Meyer-Olkin(KMO) & & & 0,926 \\
\hline Bartlett Testi & & & 0,000 \\
\hline
\end{tabular}

Faktör analizi testi sonuçları incelendiğinde ölçeğin öz değeri 1'den büyük toplam varyansın \% 56.187'sini açıklayan dört faktör altında toplandığ 1 tespit edilmiştir. Bu bağlamda 1. Faktör toplam varyansın \% 17.076'sını, 2. Faktör \% 14.834'ünü, 3. Faktör \% 13.291'ini ve 4. Faktör \% 10.986'sını açıklamaktadır. Faktör analizi sonunda sosyal 8, ekonomik 7, yönetsel 6, çevresel 3 ifadeden oluştuğu Tablo 1' den anlaşılmaktadır. Cronbach Alpha değeri ise 0,829 olarak hesaplanmıştır. Bu değer yüksek derecede güvenilir olarak kabul edilmektedir. Geçerlilik için doğrulayıcı faktör analizi kullanılmış ve Barlet Testi sonucunda $\mathrm{p}=0,000<0,05$ olduğundan değişkenler arasında ilişki olduğu kabul edilmiştir. Örnek büyüklüğün faktör analizi için uygun olup olmadığının anlaşılması üzerine yapılan test sonucunda KMO değeri 0,926 olarak hesap- 
lanmıştır. Bu değer faktör analizi açısından çok iyi bir değer olarak kabul edilmektedir (Kayış, 2010, s. 403-404). Alpha değeri ve açıklanan varyans toplamı ölçeğin güvenli ve geçerli olduğunu göstermektedir.

Verilerin çözümlenmesi için yapılan analizlerde testlerin parametrik mi yoksa non-parametrik mi uygulanacağına ilişkin ölçek değerlerinin anlamlı olup olmadığına da bakılmıştır. Bunun için ölçek bazında skewness (çarpıklik) ve kurtosis (basıklık) değerleri sırasıyla sosyal, -0,492; 0,511, ekonomik 0,741; 1,289, çevresel -0,245; 0,184, ve yönetsel $-0,190 ; 0,427$ değerleri arasında olduğu tespit edilmiştir. Değerlerin +2 ile -2 arasında olması, bu verilerin normal dağıldığı anlamına gelmektedir (George ve Mallery, 2010). Buradan hareketle parametrik testlerden T ve ANOVA testleri uygulanmıştır.

\section{Örneklem}

Bu kısımda büyükşehir belediyesine geçişe ilişkin katılımcıların tutumlarına ait frekans dağılımları verilmiştir.

Tablo 2. Katılımcıların Demografik Özelliklerine Göre Dağılımı(N=364)

\begin{tabular}{|c|c|c|c|}
\hline Değişkenler & & $\mathbf{N}$ & $\%$ \\
\hline \multirow{2}{*}{ Cinsiyet } & Erkek & 246 & 67,6 \\
\hline & Kadın & 118 & 32,4 \\
\hline \multirow{4}{*}{ Doğum Yeri } & İl merkezi & 64 & 17,6 \\
\hline & İlçe & 167 & 45,9 \\
\hline & Kasaba & 83 & 22,8 \\
\hline & Köy & 50 & 13,7 \\
\hline \multirow{6}{*}{ Yaş } & $18-25$ & 52 & 14,3 \\
\hline & $26-30$ & 142 & 39,0 \\
\hline & $31-35$ & 110 & 30,2 \\
\hline & $36-40$ & 36 & 9,9 \\
\hline & $41-45$ & 18 & 4,9 \\
\hline & 46 ve yukarısı & 6 & 1,6 \\
\hline \multirow{4}{*}{ Medeni Durum } & Evli & 168 & 46,2 \\
\hline & Bekar & 177 & 48,6 \\
\hline & Eşi ölmüş & 10 & 2,7 \\
\hline & Eşinden ayrılmış & 9 & 2,5 \\
\hline \multirow{5}{*}{ Meslek } & Kamu çalışanı veya emekli & 16 & 4,4 \\
\hline & Ücretli çalışan veya İşçi & 111 & 30,5 \\
\hline & Serbest meslek & 50 & 13,7 \\
\hline & Esnaf & 38 & 10,4 \\
\hline & Geçici Meslekler & 149 & 40,9 \\
\hline \multirow{5}{*}{ Öğrenim Durumu } & Okuryazar değil & 3 & 8 \\
\hline & İlköğretim mezunu & 158 & 43,4 \\
\hline & Lise mezunu & 151 & 41,5 \\
\hline & Ön lisans mezunu & 22 & 6,0 \\
\hline & Lisans ve lisansüstü mezunu & 30 & 8,2 \\
\hline
\end{tabular}


Tablo 2 incelendiğinde; katılımcların 246 (\% 67,6)'s1 erkek, 118 (\% 32,4)'i ise kadınlardan oluşmakta ve bunların 177 (\% 48,6)'si bekâr, 168 (\% 46,2)'i evli, geri kalanı (\% 5,2) ise eşi ölmüş veya eşinden ayrılmış olduğu anlaşılmaktadır. Katılımcların 167 (\%45,9)'si ilçe merkezinde, 83 (\% 22,8)'ü kasabada (eskiden belde belediyesi olan yerleşim alanı), 64 (\% 36,6)'ü il merkezinde doğmuş iken 50 (\% 13,7) katılımcı ise köyde (eskiden köy olan mahallede) doğduğu anlaşılmaktadır. Dolayısıyla katılımcıların büyük çoğunluğunun doğum yeri, il merkezi dışındaki diğer yerleşim yerleri olduğu söylenebilir. Gençlerin anket değerlendirmelerine daha kolay katılım sağlamaları ve kent ile ilgili konulardaki hassasiyetleri katılımcıların önemli oranın gençlerden oluşmasını sağlamıştır. Araştırmaya katılanların 304 (\% 83,5)'ü 18 ile 35 yaş arasında yer alırken, geri kalanı $(\% 16,5) 36$ ve üstü yaş aralığında olan kişilerden oluşmaktadır. Katılımcıların meslek gruplarına bakıldığında genellikle $(\% 40,9)$ geçici meslekler olarak tarif edilen gündelikçi, tablacı, çiftçi, ev hanımı, öğrenci, iş arayıp ta bulamayanlar, çalışmak istemeyenler oluşturmaktadır. Geri kalanı ise ücretli çalışan veya iş̧̧i (\% 30,5), avukat, doktor, muhasebeci vb. serbest meslek sahipleri (\% 13,7), esnaf (\% 10,4) ve kamu çalışanlarından (\% 4,4) oluşmaktadır. Katılımcıların 158 (\% 43,4)'i ilköğretim, 151 (\% $41,5)^{\prime} i$ lise, geri kalanı ise üniversite mezunudur. Katılımcların içinde az sayıda okur-yazar olmayanların yer aldığı elde edilen verilerden anlaşılmaktadir.

Tablo 3. Katılımcıların İkamet Yerlerine Göre Dağılımı(N=364)

\begin{tabular}{lll}
\hline Değişkenler & $\mathbf{N}$ & $\mathbf{\%}$ \\
\hline Merkez ilçesi & 100 & 27,5 \\
İlçe belediyesi & 234 & 64,3 \\
Büyükşehir ilçesine bağlı eskiden köy olan mahalle olanolaolamahallemahallede & 30 & 8,2 \\
\hline
\end{tabular}

Tablo 3'de, katılımcılardan 100 (\% 27,5)'ü merkez ilçede ikamet ederken, 234 (\% 64,3)'ü ilçe belediyelerinde ve 30 (\% 8,2)'u ise ilçe belediyelerine bağlı eskiden köy olan mahallede ikamet ettiği anlaşılmaktadır.

Tablo 4. Katılımcıların İkamet Sürelerine Göre Dağılımı(N=364)

\begin{tabular}{lll}
\hline Değişkenler & $\mathbf{N}$ & $\mathbf{\%}$ \\
\hline $0-5$ & 9 & 2,5 \\
$6-10$ & 74 & 20,3 \\
$11-15$ & 169 & 46,4 \\
$16-20$ & 80 & 22,0 \\
21 ve üzeri & 32 & 8,8 \\
\hline
\end{tabular}


Katılımcıların büyükşehir belediyesindeki ikamet süreleri incelendiğinde genel olarak katılımcıların çoğu $(\%$ 69,2) Büyükşehir Belediyesine geçiş olmadan önce ikamet ettikleri, geri kalanı $(\% 30,8)$ ise büyükşehir ile ilgili Kanun çıktıktan sonra Büyükşehir mülki sınırları içerisinde ikamet etmeye başladıkları anlaşılmaktadır.

Tablo 5. Katılımcılarn İllerinin Büyükşehir Belediyesi Olmasından Memnun Olup Olmadiklarına Göre Dağglımı( $N=364)$

\begin{tabular}{lll}
\hline Değişkenler & $\mathbf{N}$ & \% \\
\hline Evet, memnunum. & 283 & 77,7 \\
Hayır, memnun değilim. & 81 & 22,3 \\
\hline
\end{tabular}

Ankete katılan katılımcıların büyük çoğunluğu $(\% 77,7)$ Mardin' in büyükşehir belediyesi olmasından memnun olduğu ortaya çıkmıştır. Buradan hareketle büyüyen kentlerin büyükşehir modeli ile yönetilmesi yerel halka katkı sağladığı söylenebilir.

Tablo 6. Katılımcılarn Mardin'in Büyükşehir Belediyesi Olması ile Yaşamlarnnda Değişme Olup Olmadığına Göre Dă̆ı̆lımı(N=364)

\begin{tabular}{lll}
\hline Değişkenler & $\mathbf{N}$ & $\%$ \\
\hline Evet, olumlu oldu. & 222 & 61,0 \\
Evet, olumsuz oldu. & 47 & 12,9 \\
Hayır, olmadı. & 95 & 26,1 \\
\hline
\end{tabular}

Tablo 6 incelendiğinde, Tablo 5'te ortaya çıkan olumlu ifadelerin nedenleri ortaya çıkmaktadır. Katılımcıların yarısından fazlası (\% 61,0) Mardin'in büyükşehir belediyesi olmasından sonra yaşamlarında olumlu anlamda bir değişim olduğunu belirtirken, 95 (\% 26,1)'i ise böyle bir farklılığın ortaya çıkmadığınıbelirtmiştir. Az sayıda katılımcı ise illerinin büyükşehir belediyesi olması ile yaşamlarında $(\% 12,9)$ olumsuz yönde bir değişme meydana geldiğini ifade etmiştir.

Tablo 7. Katılımcılarn Büyükşshir Belediyesindeki İlgili Birimlere Ulaşılmasında ve Seslerini Duyurmada Sorun Yaşayıp Yaşamadıklarına Göre Dağılımı(N=364)

\begin{tabular}{lll}
\hline Değişkenler & $\mathbf{N}$ & $\%$ \\
\hline Evet, sorun yaşıyorum. & 68 & 18,7 \\
Kısmen, sorun yaşıyorum. & 243 & 66,8 \\
Hayır, sorun yaşamıyorum. & 53 & 14,6 \\
\hline
\end{tabular}

Tablo 7 incelendiğinde; katılımcıların 68 (\% 18,7)'i Büyükşehir Belediyesindeki ilgili birimlere ve yönetime kolaylıkla ulaşabildiğini ve ilgili yerlere 
seslerini duyurabildiklerini belirtirken, 243 (\% 66,8)'ü kısmen, 53 (\% 14,6)'ü ise büyükşehir belediyesindeki ilgili birimlere ulaşmakta sıkıntı çektiklerini ifade etmiştir.

Tablo 8. Katılımcılarn Büyükşehir Belediyesi Görevlilerinin Yaklaşım Tarzına İlişkin Ifadelerine Göre Dağılımı $(N=364)$

\begin{tabular}{lll}
\hline Değişkenler & F & \% \\
\hline Dostça ve samimice yaklaşım içindedirler & 148 & 40,7 \\
Bazen dostça ve samimice davranmaktadırlar & 181 & 49,7 \\
Vatandaşı küçültücü ve aşağılayııı tutum içindedirler & 35 & 9,6 \\
\hline
\end{tabular}

Tablo 8 incelendiğinde; katılımcıların 148 (\% 40,7)'i Büyükşehir Belediyesi görevlilerinin yaklaşımlarını samimi olarak görürken, 181 (\% 49,7)'i ise bazı durumlarda bu samimiyeti görebildiklerini ifade etmiştir. Geri kalanlar ise Büyükşehir Belediyesi çalışanlarının yaklaşımlarını tepeden bakan ve insanları aşağılayan bir tutum içinde olduklarını iddia etmişlerdir.

Tablo 9. Katılımcıların 6360 Sayılı Kanun'un İçeriği Hakkında Bilgi Sahibi Olup Olmadıklarına Göre Dă̆ılımı(N=364)

\begin{tabular}{lll}
\hline Değişkenler & F & \% \\
\hline Evet, bilgi sahibiyim. & 41 & 11,3 \\
Kısmen, bilgi sahibiyim. & 152 & 41,8 \\
Hayır, bilgi sahibi değilim. & 171 & 47,0 \\
\hline
\end{tabular}

Katılımcıların 6360 sayılı Kanun hakkında bilgi sahibi olup olmadıklarına ilişkin soruya katılımcıların büyük çoğunluğunun (\% 88,8) bilgi sahibi olmadığı ya da kısmen bilgi sahibi oldukları anlaşılmaktadır. Katılımcıların içinde çok az sayıda kişinin (\% 11,3) 6360 sayılı Kanun hakkında fikir sahibi olduğu söylenebilir. Buradan hareketle 6360 sayılı Kanun çıkmadan önce gerekli bilgilendirme ve tartışma ortamının sağlanmadığı, çıtıktan sonrada Kanun'un uygulamasıyla ilgili bilgilendirme yapılmadığı anlaşılmaktadır.

Tablo 10. Katılımcılarnn Büyükşsehir Belediyesi Yönetiminin Hizmet Verme Yaklaşımına İlişkin Iffadelerine Göre Dağılımı $(N=364)$

\begin{tabular}{lll}
\hline Değişkenler & F & \% \\
\hline Herkese eşit hizmet vermektedir. & 175 & 48,1 \\
Kısmen eşit hizmet vermektedir. & 114 & 31,3 \\
Hizmet vermede eşit davranmamaktadır & 75 & 20,6 \\
\hline
\end{tabular}


Tablo 10'u incelediğimizde, katılımcıların yarısına yakını (\% 48,1) büyükşehir belediyesinin herkese eşit hizmet verdiğini ve adil davrandığını belirtirken, 114 (\% 31,3)'ü kısmen, 75 (\% 20,6)'i ise büyükşehir belediyesi yönetiminin herkese eşit mesafede olmadığı düşüncesindedir. Dolayısıyla Büyükşehir Belediyesinin sağladıkları imkânlar açısından halkta yansımasının olumlu olduğu anlaşılmaktadır.

Aşağıdaki tablolarda büyükşsehir belediyesine geçişe ilişkin tutumların cinsiyet, yaş, öğrenim durumu, meslek, ikamet durumu değişkenlerine göre istatistiksel anlamda fark olup olmadığına ilişkin analizlere yer verilmiştir.

Tablo 11. Cinsiyet Değişkenine Göre Katılımcılarnn Büyükşshir Belediyesine Geçiş Sonrası Düşüncelerine İlişkin T-Testi Sonuçları

\begin{tabular}{|c|c|c|c|c|c|c|}
\hline Değişken & Cinsiyet & $\mathbf{N}$ & $\overline{\mathbf{X}}$ & S.S. & $t$ & $\mathbf{P}$ \\
\hline \multirow{2}{*}{ Sosyal } & Erkek & 246 & 3,3847 & ,59309 & \multirow{2}{*}{,-- 266} & \multirow{2}{*}{,071 } \\
\hline & Kadın & 118 & 3,2521 & ,76673 & & \\
\hline \multirow{2}{*}{ Ekonomik } & Erkek & 246 & 3,5854 & 60221 & \multirow{2}{*}{$--1,176$} & \multirow{2}{*}{,062 } \\
\hline & Kadın & 118 & 3,4504 & ,72040 & & \\
\hline \multirow{2}{*}{ Çevresel } & Erkek & 246 & 3,3675 & 64971 & \multirow{2}{*}{$--2,081$} & \multirow{2}{*}{,588 } \\
\hline & Kadın & 118 & 3,3254 & ,77252 & & \\
\hline \multirow{2}{*}{ Yönetsel } & Erkek & 246 & 3,2832 & ,71633 & \multirow{2}{*}{$-2,426$} & \multirow{2}{*}{, $011^{*}$} \\
\hline & Kadın & 118 & 3,0734 & ,77243 & & \\
\hline
\end{tabular}

${ }^{*} \mathrm{p}<0,05$

Ölçekler bakımından Tablo 11 değerlendirildiğinde; sosyal, ekonomik ve çevresel ölçeklerde $\mathrm{P}>0,05$ olduğundan cinsiyet değişkeni ile söz konusu ölçekler arasında anlamlı bir farklılık olmadığı, yönetsel boyutta $\mathrm{p}$ değerinin 0,011 olduğu ve $p<0,05$ olduğu için yönetsel boyutta katılımciların cinsiyetleri arasında istatistiksel olarak anlamlı bir farklılık olduğu söylenebilir. Aritmetik ortalamalarına baktığımızda; erkek katılımcların aritmetik ortalaması 3,2832, kadın katılımcıların aritmetik ortalaması ise 3,0734 olduğu ve erkek katılımcıların, Mardin'in büyükşehir olması sonrasında yönetsel alanda gelişmeleri kadın katılımcılara göre daha çok benimsedikleri ortaya çıkmıştır.

Tablo 12' de katılımcıların Büyükşehir Belediyesine geçiş sonrası düşünceleri ile öğrenim durumlarının karşılaştırılmasına ilişkin ANOVA testi için öncelikle varyansların homojen olup olmadığına bakılmıştır. Yapılan homojenlik testine göre sosyal $(\mathrm{p}=0,600)$, ekonomik $(\mathrm{p}=0,346)$, çevresel $(\mathrm{p}=0,204)$ ve yönetsel $(p=0,104)$ boyutların hepsinde $P>0,05$ olduğundan dolayı varyansların homojen olduğu anlaşılmıştır 
ANOVA testi sonuçlarına baktığımızda; sosyal, çevresel ve yönetsel boyutta $p$ değerlerinin sirasiyla 0,$000 ; 0,002 ; 0,003$ olduğu ve $p<0,05$ olduğundan istatistiksel olarak üç ölçekte öğrenim düzeyi açısından gruplar arasında anlamlı farklılık olduğu ortaya çıkmıştır. Ekonomik boyutta ise p değerinin 0,160 olduğu ve $p>0,05$ olduğundan istatistiksel olarak anlamlı bir farklılık olmadığı anlaşılmaktadır. Aritmetik ortalamalarına baktığımızda sosyal boyutta en yüksek ortalamanin 3,5114 değerle ön lisans veya yüksekokul mezunu olan katılımcılarda olduğu, çevresel boyutta en yüksek ortalamanın 3,8095 değerle okur-yazar olmayanlarda olduğu, yönetsel boyutta ise en yüksek ortalamanın 3,2914 değerle lise mezunu olan katılımcilarda olduğu tablodan anlaşılmaktadır.

Tablo 12. Öğrenim Durumlarna Göre Katılımcılarn Büyükşehir Belediyesine Geçiş Sonrası Düşüncelerine Göre Dağılımı

\begin{tabular}{|c|c|c|c|c|c|c|c|}
\hline Faktörler & Öğrenim Durumu & $\mathbf{N}$ & $\overline{\mathbf{x}}$ & S.S. & F & $\mathbf{P}$ & $\begin{array}{l}\text { Anlamlı } \\
\text { fark }\end{array}$ \\
\hline \multirow{5}{*}{ Sosyal } & Okuryazar değil(A) & 3 & 3,2917 & 26021 & \multirow{5}{*}{6,315} & \multirow{5}{*}{, $000^{*}$} & \multirow{5}{*}{$\begin{array}{l}\text { E-B } \\
\text { E-C } \\
\text { E-D }\end{array}$} \\
\hline & İlköğretim mezunu(B) & 158 & 3,3386 & 61905 & & & \\
\hline & Lise mezunu(C) & 151 & 3,4272 &, 52725 & & & \\
\hline & Ön lisans mezunu(D) & 22 & 3,5114 & 83176 & & & \\
\hline & Lisans ve lisansüstü mezunu(E) & 30 & 2,8083 & 1,00951 & & & \\
\hline \multirow{5}{*}{$\begin{array}{l}\text { Ekono- } \\
\text { mik }\end{array}$} & Okuryazar değil(A) & 3 & 3,8095 &, 59476 & \multirow{5}{*}{1,655} & \multirow{5}{*}{, 160 } & \\
\hline & İlköğretim mezunu(B) & 158 & 3,5759 & 63160 & & & \\
\hline & Lise mezunu $(\mathrm{C})$ & 151 & 3,5175 & ,55150 & & & \\
\hline & Ön lisans mezunu(D) & 22 & 3,7273 & ,61074 & & & \\
\hline & Lisans ve lisansüstü mezunu(E) & 30 & 3,3190 & 1,04217 & & & \\
\hline \multirow{5}{*}{ Çevresel } & Okuryazar değil(A) & 3 & 3,4667 & ,50332 & \multirow{5}{*}{4,426} & \multirow{5}{*}{, $002^{*}$} & \\
\hline & İlköğretim mezunu(B) & 158 & 3,4278 & 65946 & & & \\
\hline & Lise mezunu $(\mathrm{C})$ & 151 & 3,3603 & 63541 & & & E-B \\
\hline & Ön lisans mezunu(D) & 22 & 3,4273 & 91401 & & & $\mathrm{E}-\mathrm{C}$ \\
\hline & Lisans ve lisansüstü mezunu(E) & 30 & 2,8667 & ,79539 & & & E-D \\
\hline \multirow{5}{*}{ Yönetsel } & Okuryazar değil(A) & 3 & 2,5556 & ,76980 & \multirow{5}{*}{4,171} & \multirow{5}{*}{, $003^{*}$} & \multirow{5}{*}{$\begin{array}{l}\text { E-B } \\
\text { E-C }\end{array}$} \\
\hline & İlköğretim mezunu(B) & 158 & 3,2574 & 69870 & & & \\
\hline & Lise mezunu $(\mathrm{C})$ & 151 & 3,2914 & 69101 & & & \\
\hline & Ön lisans mezunu(D) & 22 & 3,0909 & 1,06499 & & & \\
\hline & Lisans ve lisansüstü mezunu(E) & 30 & 2,7667 & ,76389 & & & \\
\hline
\end{tabular}

${ }^{*} \mathrm{p}<0,05$

Anlamlı farklılığın hangi öğrenim düzeyleri arasında olduğunu tespit etmek için Tukey testi yapılmıştır. Yapılan Tukey testinin sonuçlarına baktığ1mızda sosyal boyutta lisans ve lisansüstü mezunlar ile ilköğretim mezunu (Fark:53027; Standart hata:12704), lise mezunu (Fark: 0,61882; Standart hata: 0,12751) ve ön lisans mezunu (Fark: 0,70303; Standart hata: 0,17905) arasında 
farklar tespit edilmiştir. Çevresel boyutta lisans ve lisansüstü mezunlar ile ilköğretim mezunu (Fark: 0,56118; Standart hata:13511), lise mezunu (Fark: 0, 49360; Standart hata: 0,13561) ve ön lisans mezunu (Fark: 0,56061; Standart hata: 0,19043) arasinda farklar tespit edilmiştir. Yönetsel boyutta lisans ve lisansüstü mezunlar ile ilköğretim mezunu (Fark: 0, 49072; Standart hata: 14496) ve lise mezunu (Fark: 0, 52472; Standart hata: 0, 14549) arasında farklar ortaya çıkmıştır. Dolayısıyla sosyal, çevresel ve yönetsel boyutlarda eğitim düzeyi açısından grup ortalamaları arasında istatiksel anlamda anlamlı farklilıklar tespit edilmiştir.

Tablo 13. Mesleklerine Göre Katılımcılarn Büyüksşehir Belediyesine Geçiş Sonrası Düşüncelerine Göre Dă̆ılımı

\begin{tabular}{|c|c|c|c|c|c|c|c|}
\hline Faktörler & Öğrenim Durumu & $\mathbf{N}$ & $\overline{\mathbf{X}}$ & S.S. & $\mathbf{F}$ & $\mathbf{P}$ & $\begin{array}{l}\text { Anlamli } \\
\text { fark }\end{array}$ \\
\hline \multirow{5}{*}{ Sosyal } & Kamu çalışanı ve emekli(A) & 16 & 3,171 & 856 & \multirow[t]{5}{*}{1,883} & \multirow[t]{5}{*}{,113 } & \\
\hline & Ücretli çalışan veya İşçi(B) & 111 & 3,477 & 601 & & & \\
\hline & Serbest meslek(C) & 50 & 3,277 & 491 & & & \\
\hline & Esnaf(D) & 38 & 3,325 &, 563 & & & \\
\hline & Geçici Meslekler (E) & 149 & 3,284 & ,729 & & & \\
\hline \multirow{5}{*}{ Ekonomik } & Kamu çalışanı ve emekli(A) & 16 & 3,6518 & ,551 & \multirow[t]{5}{*}{ 783 } & \multirow[t]{5}{*}{,537 } & \\
\hline & Ücretli çalışan veya İşçi(B) & 111 & 3,581 & ,589 & & & \\
\hline & Serbest meslek(C) & 50 & 3,525 & ,568 & & & \\
\hline & Esnaf(D) & 38 & 3,639 & 623 & & & \\
\hline & Geçici Meslekler (E) & 149 & 3,480 & ,719 & & & \\
\hline \multirow{5}{*}{ Çevresel } & Kamu çalışanı ve emekli(A) & 16 & 3,262 & ,788 & \multirow[t]{5}{*}{1,153} & \multirow[t]{5}{*}{331} & \\
\hline & Ücretli çalışan veya İşçi(B) & 111 & 3,468 & 609 & & & \\
\hline & Serbest meslek(C) & 50 & 3,276 & 625 & & & \\
\hline & Esnaf(D) & 38 & 3,331 & 728 & & & \\
\hline & Geçici Meslekler (E) & 149 & 3,310 & ,745 & & & \\
\hline \multirow{5}{*}{ Yönetsel } & Kamu çalışanı ve emekli(A) & 16 & 2,708 & 778 & \multirow[t]{5}{*}{4,006} & \multirow[t]{5}{*}{, $003^{*}$} & B-A \\
\hline & Ücretli çalışan veya İşçi(B) & 111 & 3,369 & 699 & & & B-E \\
\hline & Serbest meslek(C) & 50 & 3,293 & 619 & & & C-A \\
\hline & Esnaf(D) & 38 & 3,254 & 650 & & & \\
\hline & Geçici Meslekler (E) & 149 & 3,118 & 793 & & & \\
\hline
\end{tabular}

${ }^{*} \mathrm{p}<0,05$

Tablo 13'de katılımcıların Büyükşehir Belediyesine geçiş sonrası düşünceleri ile mesleklerinin karşılaştırılmasına ilişkin ANOVA testi için öncelikle varyansların homojen olup olmadığına bakılmıştır. Yapılan homojenlik testine göre sosyal $(p=0,07)$, ekonomik $(p=0,689)$, çevresel $(p=0,0666)$ ve yönetsel $(\mathrm{p}=0,671)$ boyutlarda $\mathrm{p}>0,005$ olduğundan varyanslar homojen olarak kabul edilmektedir. 
Varyansların homojen olmasının ardından ANOVA değerlerine baktı̆̆1mızda sosyal, ekonomik ve çevresel boyutta p değerlerinin sırasıyla 0,113; 0,537; 0,331 olduğu ve $p>0,05$ olduğundan istatistiksel olarak üç ölçekte de meslek grupları açısından Büyükşehir Belediyesine geçiş sonrası katılımcıların düşünceleri arasında anlamlı farklılık olmadığı ortaya çıkmıştır. Yönetsel boyutta ise $p$ değerinin 0,003 olduğu ve $\mathrm{P}<0,05$ olduğundan istatistiksel olarak grup ortalamaları arasında anlamlı bir farklılık olduğu anlaşılmış ve en yüksek aritmetik ortalamanın 3,3694 değerle ücretli çalışan veya İşçi olan katılımcılarda olduğu ortaya çıkmıştır. Anlamlı farklılığın hangi meslek grubundan kaynaklandığını tespit etmek için varyansların homojen olması nedeniyle Tukey testi yapılmıştır. Yapılan Tukey testinin sonuçlarına baktığımızda yönetsel boyutta anlamlı farklılıkların ücretli çalışan veya İşçi ile kamu çalışanı (Fark: 0,66104; Standart hata: 0, 19481) ve geçici meslek (gündelikçi, tablacı, çiftçi, ev hanımı, öğrenci, iş arayıp ta bulamayanlar, çalışmak istemeyenler vd.) grupları arasında (Fark: 0,25080; Standart hata: 0, 09134); serbest meslek ile kamu çalışanı grupları arasında (Fark: 0,58500; Standart hata: 0, 20925) anlamlı bir fark tespit edilmiştir.

Tablo 14. Yaşlarına Göre Katılımcılarnn Büyükşehir Belediyesine Geçiş Sonrası Düşüncelerine Göre Dă̆ılımı

\begin{tabular}{|c|c|c|c|c|c|c|c|}
\hline Faktörler & Yaş & $\mathbf{N}$ & $\overline{\mathbf{X}}$ & S.S & $\mathbf{F}$ & $\mathbf{P}$ & \\
\hline & $18-25(\mathrm{~A})$ & 52 & 3,1322 & 86935 & & & \\
\hline & $26-30(\mathrm{~B})$ & 142 & 3,3327 & ,62843 & & & \\
\hline \multirow[t]{5}{*}{ Sosyal } & $31-35(C)$ & 110 & 3,4398 & ,59642 & 2,112 & 079 & \\
\hline & $36-40$ (D) & 36 & 3,4132 & 47979 & & & \\
\hline & 41 ve üzeri(E) & 24 & 3,2917 & ,71348 & & & \\
\hline & $18-25(\mathrm{~A})$ & 52 & 3,4176 & ,88147 & & & \\
\hline & 26-30(B) & 142 & 3,4306 & ,62583 & & & \\
\hline \multirow[t]{5}{*}{ Ekonomik } & $31-35(\mathrm{C})$ & 110 & 3,6948 & ,52265 & 4,081 &, $003^{*}$ & \\
\hline & $36-40(\mathrm{D})$ & 36 & 3,7341 & ,59164 & & & C-B \\
\hline & 41 ve üzeri(E) & 24 & 3,4762 &, 57401 & & & \\
\hline & $18-25(\mathrm{~A})$ & 52 & 3,0692 & 84842 & & & \\
\hline & $26-30(\mathrm{~B})$ & 142 & 3,3944 & ,63467 & & & \\
\hline \multirow[t]{5}{*}{ Çevresel } & $31-35(C)$ & 110 & 3,4855 & ,62572 & 5,271 &, $000^{*}$ & C-A \\
\hline & $36-40(\mathrm{D})$ & 36 & 3,4389 & 69746 & & & C-E \\
\hline & 41 ve üzeri(E) & 24 & 3,0000 & 67759 & & & \\
\hline & $18-25(\mathrm{~A})$ & 52 & 2,9679 & 88625 & & & \\
\hline & $26-30(\mathrm{~B})$ & 142 & 3,2254 & 68824 & & & \\
\hline \multirow[t]{3}{*}{ Yönetsel } & $31-35(\mathrm{C})$ & 110 & 3,3333 & ,76360 & 2,229 & ,065 & \\
\hline & $36-40(\mathrm{D})$ & 36 & 3,2130 & ,63322 & & & \\
\hline & 41 ve üzeri(E) & 24 & 3,1528 & ,65186 & & & \\
\hline
\end{tabular}

${ }^{*} \mathrm{p}<0,05$ 
Tablo 14'de katılımcların Büyükşehir Belediyesine geçiş sonrası düşünceleri ile yaşlarının karşılaştırılmasına ilişkin ANOVA testi için öncelikle varyansların homojen olup olmadığına bakılmıştır. Yapılan homojenlik testine göre ekonomik ( $\mathrm{p}=0,013)$, çevresel $(\mathrm{p}=0,116)$ ve yönetsel $(\mathrm{p}=0,350)$ boyutlarda $p>0,005$ olduğundan varyanslar homojen olarak kabul edilmektedir. Ancak sosyal $(\mathrm{p}=0,01)$ boyutta varyansların homojen olmadığı anlaşılmıştır.

Varyansların homojenliği test edildikten sonra yapılan ANOVA testinde yönetsel boyutta $p$ değerlerinin 0,65 olduğu ve $p>0,05$ olduğundan istatistiksel olarak anlamlı farklılık olmadığı ortaya çıkmıştır. Ekonomik ve çevresel boyutta ise $p$ değerinin sırasıyla $p=0,003 ; p=0,000$ olduğu ve iki ölçekte de $\mathrm{P}<0,05$ olduğundan istatistiksel olarak anlamlı farklılık olduğu ortaya çıkmıştır. Söz konusu ölçeklerde en yüksek aritmetik ortalamaya sahip gruplar ise, ekonomik boyutta 3,7341değer ile 31-35 yaş grubu, çevresel boyutta ise 3,4855 değerle 31-35 yaş grubu olduğu anlaşılmaktadır. Anlamlı farklılığın hangi yaş grubundan kaynaklandığını tespit etmek için varyansların homojen olması nedeniyle Tukey testi yapılmıştır. Yapılan Tukey testinin sonuçlarına baktığımızda ekonomik boyutta anlamlı farklılıkların 31-35 yaş grubu ile 2630 yaş grubu (Fark: 0,26422; Standart hata: 0,08057) arasında, çevresel boyutta 31-35 yaş grubu (Fark: 0, 41622; Standart hata: 0, 11367) ile 18-25 ve 41 ve üzeri (Fark: 0, 48545; Standart hata: 0, 15217) yaş grupları arasında anlamlı bir farklilık tespit edilmiştir.

Tablo 15. İkamet Yerlerine Göre Katılımcıların Büyükş̧ehir Belediyesine Geçiş Sonrası Düşüncelerine Göre Dağılımı

\begin{tabular}{|c|c|c|c|c|c|}
\hline Faktörle & İkamet Yeri & $\mathbf{N}$ & $\overline{\mathbf{X}}$ & S.S. & $\mathbf{P}$ \\
\hline \multirow[t]{3}{*}{ Sosyal } & Büyükşehir Belediyesi Merkez İlçesinden & 100 & 3,2963 & 76059 & \multirow{3}{*}{$2,642,097$} \\
\hline & Büyükşehir Belediye İlçesinden & 234 & 3,3878 & 62342 & \\
\hline & Büyükşehir ilçesine bağlı eskiden köy olan mahallede & 30 & 3,1333 & 47449 & \\
\hline \multirow[t]{3}{*}{ Ekonomik } & Büyükşehir Belediyesi Merkez İlçesinden & 100 & 3,4643 & 68327 & \multirow{3}{*}{$7,762,327$} \\
\hline & Büyükşehir Belediye İlçesinden & 234 & 3,5781 & 61956 & \\
\hline & Büyükşehir ilçesine bağlı eskiden köy olan mahallede & 30 & 3,5143 & ,70546 & \\
\hline \multirow[t]{3}{*}{ Çevresel } & Büyükşehir Belediyesi Merkez İlçesinden & 100 & 3,1700 & 77192 & \multirow{3}{*}{$6,857,001^{*}$} \\
\hline & Büyükşehir Belediye İlçesinden & 234 & 3,4547 & 62871 & \\
\hline & Büyükşehir ilçesine bağlı eskiden köy olan mahallede & 30 & 3,1800 & ,73410 & \\
\hline \multirow[t]{3}{*}{ Yönetsel } & Büyükşehir Belediyesi Merkez İlçesinden & 100 & 3,1733 & 84152 & \multirow{3}{*}{ 108, 034 } \\
\hline & Büyükşehir Belediye İlçesinden & 234 & 3,2721 & 68400 & \\
\hline & Büyükşehir ilçesine bağlı eskiden köy olan mahallede & 30 & 2,9111 & ,74758 & \\
\hline
\end{tabular}

${ }^{*} \mathrm{p}<0,05$ 
Tablo 15'de katılımcıların Büyükşehir Belediyesine geçiş sonrası düşünceleri ile ikamet ettikleri yerlerin karşılaştırılmasına ilişkin ANOVA testi için öncelikle varyansların homojen olup olmadığına bakılmıştır. Yapılan homojenlik testine göre sosyal $(p=0,11)$, ekonomik $(p=0,725)$, çevresel $(p=0,095)$ ve yönetsel $(p=0,055)$ boyutlarda $p>0,005$ olduğu için varyanslar homojen olarak kabul edilmektedir. Varyansların homojenliği test edildikten sonra yapılan ANOVA testinde sosyal, ekonomik ve yönetsel boyutlarda p değerlerinin s1rasiyla 0,097; 0,327;0,034 olduğu ve p>0,05 olduğundan istatistiksel olarak üç ölçekte de ikamet edilen yer açısından Büyükşehir Belediyesine geçiş sonrası katılımcıların düşünceleri arasında anlamlı farklılık olmadığı ortaya çıkmıştrr. Çevresel boyutta ise $p$ değerinin 0,001 olduğu ve $P<0,05$ olduğundan istatistiksel olarak çevresel ölçekte ikamet edilen yer açısından katılımcı grupları arasında Büyükşehir Belediyesine ilişkin düşüncelerinde anlamlı farklılık olduğu ortaya çıkmıştır. Söz konusu ölçekte en yüksek aritmetik ortalamaya sahip gruplar ise 3,4547 değer ile büyükşehir belediye ilçesindeki katılımc1 grupta olduğu anlaşılmaktadır.

\section{Tartışma ve Sonuç}

Türkiye'de büyük kentlerle ilgili son yirmi yılda yapılan temel düzenlemelerle, daha etkin ve kaliteli hizmet sunumunu esas alan, yerel katılımı ve dolayısıyla yerel halkın hayatını kolaylaştıran bir yaklaşım hayata geçirilmeye çalışılmıştır. Ancak yerel yönetimlerle ilgili reform çalışmaları kapsamında çıkarılan kanun tasarıları ve diğer düzenlemelerin, kamuoyunda yeterince tartışılmaması ile başta yetki ve hizmet olmak üzere denetim, koordinasyon, temsil, katılım ve bütünşehire özgü fiziksel engeller gibi birçok yerel bazlı sorunsalın ihmal edildiği ortaya çıkmıştır. Dolayısıyla büyükşehire geçiş sonrası her ne kadar yerel halkın yaşamında önemli değişimler yaşanmış olsa da, hedeflenen amaçların uygulamada yapılanlarla örtüşememesi nedeniyle bazı durumlarda hayal kırıklıkları da ortaya çıkabilmiştir. Bu çerçevede ela alınan çalışmamızda, 2012 yılında yürürlüğe giren ve 2014 yılında fiili olarak uygulanmaya başlanan 6360 sayılı Kanun'un, geçen zaman diliminde yerel halkta yansıması ve yerel halkın bu konudaki görüşlerinin belirlenmesi amacı ile gerçekleştirilmiştir. Bu araştırmanın amaçları doğrultusunda bulgulardan elde edilen sonuçlar şu şekilde özetlenebilir:

- Araştırma kapsamında görüşleri alınan katılımcların büyük oranı büyükşehir belediye ilçesinden, geri kalanı ise büyükşehir belediyesi merkez 
ilçesi ile büyükşehir ilçesine bağlı eskiden köy olan mahalleden olduğu ortaya çıkmıştır. Katılımcıların genel olarak sekiz yıldan daha fazla bir sürede büyükşehir sınırları içinde ikamet ettikleri ve dolayısıyla büyükşehir statüsüne geçmeden önce katılımcıların ikamet ettikleri yerlerde yaşadıkları elde edilen bulgulardan anlaşılmaktadır. Diğer taraftan katılımcıların Mardin'in büyükşehir belediyesi olmasından memnun oldukları ve kentin büyükşehir olduktan sonra yaşamlarında önemli oranda farklılıklar yarattı̆ını ifade etmelerine rağmen 6360 sayılı Kanun hakkında hala yeterli derecede bilgi sahibi olamadıkları anlaşılmaktadır. Bunun nedeni olarak 6360 sayılı Kanun yasalaşmadan önce, kanun taslağ 1 ile ilgili gerekli bilgilendirme ve tartışmalar yapılmamasından kaynaklandığı söylenebilir. Buna karşın Kaçmaz ve Er (2018)'in Alanya'da, Özaslan ve arkadaşlarının (2014) Muğla'da gerçekleştirdiği çalışmalarda, 6360 sayılı Kanun hakkında yerel halkın yeterince bilgi sahibi olduklarına ilişkin bulgular elde edildiği belirtilmiştir. Diğer taraftan Kaypak ve Yılmaz (2016)'ın Van'da, Karasu (2014)'nun Şanlıurfa'da, İzci ve Turan (2013)'ın Van'da, Belli ve Aydın (2016)'ın Kahramanmaraş'ta, Usta, Akman ve Kocaoğlu (2018)'nun Konya'da yapmış olduğu araştırmalarda, büyükşehire ilişkin getirilen düzenlemelerle yerel halka hizmet sunumunda artış yaşandığı ve yerel halkın yaşamında farklılıklar meydana getirdiği belirtilmiştir. Ancak Bulut ve Dönmez (2019)'in Hatay'da, Ökmen ve Arslan (2014)'ın Manisa'da, Genç ve Korkın (2017)'ın Aydın'da ve Sezik (2015)'in Malatya'da yaptığı çalışmada farklı sonuçlar ortaya çıkmıştır. Buna göre büyükşehir belediyesine geçişle birlikte hizmet sunumunda etkinlik ve verimliliğin sağlanamadığı yönünde görüşler ileri sürülmüştür. Dolayısıyla farklı ölçeklerde yapılan araştırmalarda benzer ve farklı yorumlar ortaya çıkabilmektedir.

Katılımcıların büyükşehrin çalışmalarına ve yönetsel faaliyetlerine katılmaları ve yönetsel karar mekanizmalarında temsil edilmeleri açısından bakıldığında, yönetime katılma konusunda zayıf kalındığı, yerel halkın belediye yönetim birimleriyle ilişki içine giremedikleri ve bu durumun belediye çalışanlarının yaklaşımı nedeniyle ortaya çıktığı söylenebilir. Genç (2014)'in Aydın'da, Kaçmaz ve Er (2018)'in Alanya örneğinde yaptığı çalışmada farklı sonuçlar ortaya çıkmıştır. Bu çalışmalara göre, büyükşehir belediye modelinin temsil ve katılımı sağladığı ve yerel halkın birçok alanda belediye yönetimiyle aktif ilişki içinde olduğu ortaya çıkmıştır. Diğer taraftan katılımcıların yarısına yakını Mardin Büyükşehir Belediyesi'nin herkese eşit hizmet verdiği 
ve Belediyenin hizmet verme konusunda tarafsız bir tutum içinde olduğu belirtilmiştir. Buna karşın Arıkboğa (2014)'nın Bursa örneğinde yaptığı çalışmada siyasi ve coğrafi temsiliyet konusunda Büyükşehir Belediyesinin hizmet sunumunda ortaya çıkan adaletsiz uygulamalarına dikkat çekilmiştir. Araştırma amacına yönelik faktörlere ilişkin yapılan analizlerde katılımcıların konu ile ilgi görüşleri "sosyal hizmetler", "ekonomik hizmetler", "çevresel hizmetler" ve "yönetsel hizmetler" olarak isimlendirilen dört faktörden meydana gelmiş ve katılımcıların demografik özellikleri ile faktörler arasında belli ölçülerde istatistiksel olarak anlamlı farklılıklar tespit edilmiştir. Buna göre yapılan $T$ testi analizinde, katılımcıların cinsiyetleri bakımından yönetsel boyutta grup ortalamaları arasinda istatistiksel olarak anlamlı farklar ortaya çıkmıştır. Benzer şekilde yapılan ANOVA testi analizinde katılımcıların eğitim düzeyleri açısından sosyal, çevresel ve yönetsel boyutlarda; katılımclların meslekleri açısından yönetsel boyutta; katılımcıların yaşları açısından ekonomik ve çevresel boyutta grup ortalamaları arasında istatistiksel olarak anlamlı farklar tespit edilmiştir. Bu anlamlı farklılıklar, genel olarak erkeklerin kadınlara, eğitim düzeyi yüksek olanların eğitim düzeyi düşük olanlara, ücretli çalışan, işçi, serbest meslek erbabının diğer meslek guplarına göre, 3135 yaş grubundakilerin diğer yaş gruplarına göre büyükşehire ilişkin tutumlarının farklı olduğu ve bu farklılığın olumlu yönde olduğu anlaşılmıştır.

Yukarıda yer alan bütün bulgular ışığında bu çalışma ortaya koymaktadır ki 6360 sayılı Kanun eskiye göre daha iyi gelişmeler ortaya koymuş olsa da, demokratik temsil ve katılım açısından merkez-yerel ilişkilerinin arzu edilen seviyeye ulaşamadığı görülmüştür. Yine de büyükşehir modeline geçişle birlikte ortaya çıkan yerel hizmet anlayışından yerel halkın genel olarak memnun olduğu söylenebilir. Dolayısıyla yeni büyükşehir modelinin yerel yönetim anlayışına önemli katkısı olmasına rağmen daha yerelden bir bakış açısyyla yeniden düzenlemeye ihtiyaç olduğu gerçeği şüphe götürmezdir. Buradan hareketle başta yerel yönetimlerle ilgili reform çalışmalarında özgürlük, etkinlik ve demokrasi temelinde yerel motiflerin ve bilimsel kriterlerin esas alınması, merkezi yönetimin yetki alanının büyükşehir yönetimi lehine sınırlandırılması, temsil ve katılımın uygulamada sorunsuz bir şekilde gerçekleşmesi için gerekli yasal ve idari düzenlemelerin yeniden gözden geçirilmesi ve büyük kentlerin özelliklerine göre modellerin hayata geçirilmesi önem kazanmaktadir. 


\section{EXTENDED ABSTRACT}

\section{Reflections of the New Metropolitan Municipality Model Application to Local People in the Example of Mardin Metropolitan Municipality}

Muzaffer Bimay

Batman University

In the last two centuries, it has been observed that it has become increasingly difficult in terms of administrative and financial terms to provide public services and political participation needed by growing cities in the world and in our country. In this framework, important debates have been held from time to time about what kind of governance the local administrations, which are indispensable elements of democracy, hold in terms of authority and responsibility and about what the limits of democracy will be. As a result of these discussions, it has been understood that the increasing problems and diversifying needs of big cities cannot be solved with old-style urban management models, and it has emerged that new local government models or revision of existing ones are needed to solve these problems and meet the needs. For this reason, many urban models have been introduced in the world and in our country, especially with the effect of new understandings that have emerged in public administration since the 1980s, and necessary legislative changes have been made. The Metropolitan model in Turkey kept under protection in both legal and constitutional terms after the 1980s was reformed by means of the act numbered 6360 in 2012. However, the disputes with regards to the content and practices of the act are still carrying on. Thanks to basic arrangements made during the last thirty years in the large cities of Turkey, an approach based on more effective and quality service provision, which facilitates local participation and therefore the lives of local people, has been implemented. However, within the scope of reform studies regarding local administrations, it has been revealed that many local problematic issues such as authority and service, supervision, coordination, representation, participation and physical barriers specific to the whole city have been neglected. Therefore, although there have been important changes in the lives of the local people after the transition to the metropolitan city, disappointments have 
also arisen in some cases due to the inability of the targeted goals to match what has been done in practice. This study aims to take into account the reflections of the law in practice in the last eight years in Mardin, which has existed as a local administration unit since 1867 and gained metropolitan status with the act numbered 6360, enacted in 2012, through the attitudes of the local people. In other words, the approaches and perceptions of the local people living in Mardin regarding the new metropolitan local administration model put into practice with the act numbered 6360, were examined.

The quantitative research method was adopted for the study, and after the theoretical background, the findings were interpreted by making descriptive or descriptive statistics. Survey technique was preferred as the method and tool of data collection and a questionnaire consisting of closed-ended questions was prepared. By this method, it is aimed to obtain data through a list of questions that the people from whom the data will be obtained will be answered by reading directly. While preparing the questionnaire, many applied scientific studies on this subject were also used. The questionnaire consisted of multiple choice and five-point likert scale questions. Surveys, 364 face-toface interviews were conducted with a total of 364 people over the age of 18 living within the borders of Mardin Metropolitan Municipality and who accepted to do the survey and constitute the research universe. The scope of the study was limited to Mardin Metropolitan Municipality due to the limitation of resources and time. The descriptive statistics of the data obtained through the questionnaire were made through the SPSS 24 program. Thus, in order to measure satisfaction levels, arithmetic average and proportional frequencies, which are measures of descriptive statistics, were used in the study. Factor analysis was performed for the reliability and validity of the data collection tool and the differences between the obtained factors and the demographic variables of the participants were examined and Anova tests were conducted.

Based on the data obtained, it can be said that the participants approach the new metropolitan model positively, but see this model inadequate in many aspects such as authority, supervision, representation and participation. More clearly, since the enactment of the act numbered 6360, it has been observed that the effects on the local people are positive and cause significant changes in the lives of the local people. However, in terms of ensuring democratic representation and participation, it can be said that the center-local relations cannot reach the desired level both in the content and implementation 
of the act. In addition, It has been determined that the participants still do not have sufficient information about the act 6360, have difficulties in participating in the administrative activities of the Metropolitan Municipality, and have difficulties in establishing direct relations with the municipal administrative units. In the $\mathrm{T}$ test analysis, statistically significant differences were determined between the group averages in the administrative dimension in terms of the gender of the participants. Similarly, As a result of ANOVA test analysis; in social, environmental and administrative dimensions in terms of the education levels of the participants; in the managerial dimension in terms of the professions of the participants; Statistically significant differences were determined between the group averages in economic and environmental dimensions in terms of the age of the participants. These significant differences indicate that the attitudes towards the metropolitan area are positive and different among men in general, those with a high level of education compared to those with a low education level, wage earners, workers, self-employed people compared to other occupational groups, and those in the 31-35 age group compared to other age groups, and this difference has a positive effect. Thus, similar and different interpretations of this study have emerged with studies conducted at different scales.

As a result, this study reveals that although the act numbered 6360 showed better developments than before, it was observed that center-local relations did not reach the desired level in terms of democratic representation and participation. Nevertheless, it can be said that the local people are generally satisfied with the local service understanding that emerged with the transition to the metropolitan model. Therefore, although the new metropolitan model has a significant contribution to the understanding of local administration, the fact that it needs to be reorganized with a more local perspective is beyond doubt. From this point of view, the necessary legal and administrative arrangements should be reconsidered in order to ensure that local motives and scientific criteria are based on freedom, efficiency and democracy, the central government's jurisdiction is limited in favor of the metropolitan administration, and representation and participation can be carried out smoothly in practice. Moreover, implementing models according to the characteristics of big cities gains importance. 


\section{Kaynakça / References}

Adıgüzel Ş. (2018). Avrupa Konseyi Yerel Yönetimler Özerklik Şartı Çerçevesinde büyükşehir-bütünşehir düzenlemeleri. Çağdaş Yerel Yönetimler Dergisi, 27(4), 1-28.

$\mathrm{Al}, \mathrm{H}$. (1996). Cumhuriyet dönemi belediyeciliğinin tarihsel gelişimi. V. Akyüz ve S. Ünlü (Der.), İslam Geleneğinden Günümüze Şehir ve Yerel Yönetimler içinde (s. 2157), Cilt II, İstanbul: İke Yayınları.

Apan A. (2016). Bütünşehir modeli ve taşra yönetimine etkileri. Çağdaş Yerel Yönetimler Dergisi, 25(1), 1-24.

Arıkboğa, E. (2013). Geçmişten geleceğe büyükşehir modeli. Yerel Politikalar Dergisi, 4896.

Arıkboğa, E. (2014). Büyükşehir Belediye Meclislerindeki temsil adaletsizliğinin coğrafi ve siyasi görünümleri. Marmara Üniversitesi Siyasal Bilimler Dergisi, 2(2), 35-61. https: //doi: 10.14782/sbd.201439372.

Belli, A. ve Aydın, A. (2016). 6360 Sayll Yasa ile kapatılan belde belediyelerinin hizmette etkinlik, verimlilik ve temsil sorunsalı üzerine bir alan araştırması:Önsen Belediyesi örneği. Uluslararası Sosyal Araştırmalar Dergisi, 9(43), 1698-1713.

Bingöl, Y., Yazıcı, E. ve Büyükakın, T. (2013). Il Sinırnda Büyükşehir Belediye modeli: Kocaeli Deneyimi. Kocaeli Büyükşehir Belediyesi Basın Yayın ve Halkla İlişkiler Dairesi Başkanlığı Yayınları Yayın No: 38.

Bowornwathana, B. ve Poocharoen O., O. (2005). Managing reforms: The politics of organizing reform work. Public Organisation Review: A Global Journal, 5(3), 233247. 12.05.2020 tarihinde https: //Link. Springer.Com/ Content/Pdf/ 10.1007/S11115-005-0950-Z.Pdf. adresinden erişildi.

Bulut Y. ve Dönmez, D. (2019). 6360 sayll düzenlemeyle oluşan büyükşehir modelinde büyükşehir belediyesi ile ilçebelediyeleri arasında yaşanan sorunlar ve çözüm önerileri: Hatay İli örneği. Uluslararası Yönetim Akademisi Dergisi, 2(1), 29-40, https://doi.org/10.33712/mana.551905.

Can, A. (2017). SPSS ile bilimsel araştırma sürecinde nicel veri analizi, (5. Baskı), Ankara: Pegem Akademi.

Çalcalı, Ö. (2014). 6360 Sayllı Kanun'un Türkiye'de yerel yönetimler sistemine getireceği değişiklikler. Çă̆daş Yerel Yönetimler, 23(4), 49-68.

Çelik, M. L. ve Alttparmak C.(2013). Hukuki açıdan 100 soruda yeni büyü̈şehir belediye modeli. Ankara: Seçkin Yayıncllk.

Çınar, T., Çiner, C. U. ve Zengin, O. (2009). Büyükşehir Yönetimi bütünleştirme Süreci. 1. Baskl, Ankara: TODAiE Yayınları.

Çolak, H., Sağlam, H. ve Topal, A. (2017). Bütünşehir modelinin 2014 büyükşehir belediye başkanlı̆̆ seçimlerine etkileri. Çağdaş Yerel Yönetimler, 26(29), 1-47. 
Çukurçayır, M. A. (2012). Siyasal katılma ve yerel demokrasi. Konya: Çizgi Kitabevi Yayınları.

Davis K. (1965). The urbanization of the human population. Scientific American, 213(3), 40-53. 14.05.2020 tarihinde https://www.jstor.org/stable/pdf/24931110.pdf? adresinden erişildi.

DeHoog, R., D. Lowery ve W. Lyons (1991). Metropolitan fragmentation and suburban ghettos: Some empirical observations on institutional racism. Journal of Urban Affairs, 13(4), 479-493. https://doi.org/10.1111/j.1467-9906.1991.tb00268.x

Department of Economic and Social Affairs [UN DESA], (2018). 25.05.2020 tarihinde https://www.un.org/development/desa/publications/pdf adresinden erişildi.

Eke, A. E. (1982). Anakent yönetimi ve yönetimlerarast ilişkiler. Ankara: A.Ü.S.B.F. Yayınları.

Emini, F. T. (2009). Türkiye'de yerel yönetimler reformunun iç ve dış dinamikleri. Yönetim ve Ekonomi Dergisi, 16(2), 31-48.

Frey, W. H. ve Zimmer, Z.(2001). Defining the city. Ronan Paddison (Der.), Handbook of Urban Studies içinde (ss. 14-35), London: Sage Publications,

Genç, F. N. (2014). 6360 Sayılı Kanun ve Aydın'a etkileri. Adnan Menderes Üniversitesi Sosyal Bilimler Enstitüsü Dergisi, 1 (Özel Sayl), 1-29.

Genç, F. N. ve Korkın, E. (2017). 6360 Sayılı Kanun'la Tüzel Kişiliği Kaldırılan Belde Belediyelerinde Halkın Uygulamaya İlişkin Algıss: Atça (Sultanhisar-Aydın) Örneği. KMÜ Sosyal ve Ekonomik Araştirmalar Dergisi, 19 (32), 84-95.

Görmez, K. (1993). Türkiye'de anakent yönetiminin sorunları. Çă̆daş Yerel Yönetimler, 2(1), 19-29.

Gözler, K. (2013). 6360 Sayll Kanun hakkında eleştiriler: Yirmi dokuz ilde il özel idareleri ve köylerin kaldırılması ve ilçe belediyelerinin büyükşehir ilçe belediyelerine dönüştürülmesi anayasamıza uygun mudur? Legal Hukuk Dergisi, 11(22), 37-82.

Güler, B. A. (1987). Büyük kentler için yönetim araysşları. Türk İdare Dergisi, 59(374), 117144.

Huot,J., L., Thalmann, J., P. ve Valbelle D. (2000). Kentlerin doğuşu. (A. B. Girgin, Çev.), Ankara: İmge Kitabevi.

İspir, E. (1982). Kentleşmeve metropolitan alan yönetimi. Ankara: AïTİ Akademisi Yayınevi İzci, T. ve Turan, M., (2013). Türkiye'de büyükşehir belediyesi ve 6360 sayll yasa ile büyükşehir belediye sistemindemeydana gelen değişimler: Van örneği. Süleyman Demirel Üniversitesi IÏBF Dergisi, 18(1), 117-152.

Kaçmaz Y. ve Er A. (2018).Yeni büyükşehir belediye sistemine yönelik kamuoyu algisı vememnuniyet düzeyi: Alanya örneği. Süleyman Demirel Üniversitesi İ̈BF Dergisi, 23(2), 605-629. 
Karasu, M.A. (2014). Şanlıurfa kentsel gelişmesi ve 6360 sayll büyükşehir belediyesi kanunu. Adnan Menderes Üniversitesi Sosyal Bilimler Enstitüsü Dergisi, 1(Özel Sayl), 178-193.

Kavruk, H. (2002). Anakente bakıs, Türkiye'de Anakent belediyeciliüi ve kent hizmetlerinin yönetimi. Ankara: Hizmet-İş Yayınları.

Kaypak, Ş. ve Yılmaz, V. (2017). Yeni Büyükşehir uygulamasının yerel halk üzerindeki etkileri: Van örneği. Van Yüzüncü Yıl Üniversitesi Sosyal Bilimler Enstitüsü Dergisi, 124-135.

Keleş, R. (1985). Türkiye'de anakent yönetimi. Amme İdaresi Dergisi, 18(1), 69-82.

Keleş, R.(1998). Yerinden Yönetim ve Siyaset. 3. Baskı, İstanbul: Cem Yayınevi.

Koçak, S. Y. ve Ekşi A. (2010). Katıllımallk ve Demokrasi Perspektifinden Türkiye'de Yerel Yönetimler. SDÜ Fen Edebiyat Fakültesi Sosyal Bilimler Dergisi, 21, 295-307.

Lefevre, C. (1998). Metropolitan goverment and govarnance in western countries: A Critical rewiew. İternational Journal Of Urban and Regional Research, 22(1), 9-25. https://doi.org/10.1111/1468-2427.00120.

MacLeod, G. ve Jones, M. (2011). Renewing urban politics. Urban Studies, 48(12) 24432472.

Mumford, L. (2007). Tarih boyunca kent kökenleri, geçirdiği dönüşümler ve geleceği. (G.Koca ve T.Tosun, Çev.), İstanbul: Ayrıntı Yayınları.

Onyango,A. O.(2018). Global and regional trends of urbanization: A critical review of the environmental and economic imprints. World Environment 8(2), 47-62. https://doi.org/10.5923/j.env.20180802.03.

Ökmen, M. ve Arslan, R. (2014). Türkiye'de 6360 sayll yasa ileyeni kurulan büyükş̧ehir belediyeleri: Manisa Büyükşehir Belediyesi örneği. Adnan Menderes Üniversitesi Sosyal Bilimler Enstitüsü Dergisi, 1 (5), 88-101.https://doi.org/10.30803/adusobed.188831

Ökmen, M., ve Parlak, B. (2015). Yerel yönetimlerde yeni vizyonlar. Bursa: Ekin Basım Yayın Dağitım.

Özaslan, R., Kızılboğa, H. A. ve Özaslan K.(2014). 6360 Saylı Kanun Çerçevesinde Gümüşlük Belde Belediyesinin Kapatılmasına İlişkin Yöre Halkının Algısı. Marmara Üniversitesi İ.I.B. Dergisi, 16(2), 215-235.

Özgür, H. (2007). Orta ölçekli kentsel alanların yönetimineilişkin alternatifler. H. Özgür, M. Kösecik(Der.). Yerel Yönetimler Üzerine Güncel Yazlar-II içinde (ss.94-115), Ankara: Nobel Yayın Dağıtım.

Parlak, B. (2013). Yeni büyükş̧ehir belediye yasasının analizi. Yerel Yönetim Dergisi, 5(23), 38-40. 
Punch, K. F. (2011). Sosyal araştırmalara giriş/nicel ve nitel yaklaşımlar. (D. Bayrak, H. B. Arslan ve Z. Akyüz, Çev.), Ankara: Siyasal Kitapevi.

Rydergard, E. H. (2012). Belediyelerin birleştirilmesi. Teori, metodoloji ve uluslararası deneyimler. Türk-İsveç Yerel Yönetim Ortaklığı (TUSELOG).

Sezik, M. (2015). 6360 Saylı Kanun'a Göre büyükşshirlerde bütünleşme sürecinin etkileri: Malatya örneği. Yayımlanmamış Doktora Tezi, İnönü Üniversitesi SBE, Malatya.

Sjoberg G. (2002). Sanayiöncesi kenti, 20. yüzyıl kenti. (B. Duru ve A. Alkan, Haz.), Ankara: İmge Kitabevi

Tortop, N., Aykaç, B., Yayman, H, ve Özer, M.A., (2014). Mahalli idareler. Ankara: NOBEL Akademik Yayıncilı.

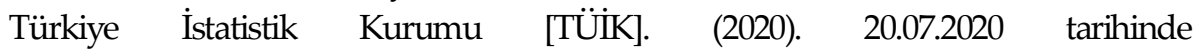
http://www.tuik.gov.tr/UstMenu.do?metod=temelist adresinden erişildi.

Usta, S., Akman E. ve Kocaoğlu M. (2018). 6360 Sayılı Kanun'un büyükşehir belediye sistemine etkileri: Konya Büyükşehir Belediyesi örneği. Tesam Akademi Dergisi, Yerel Yönetimler Özel Sayısı, 217 - 249. http://dx.doi.org/10.30626/.

Ünal, A. ve Tanrıvermiş, H. (2018). 6360 Sayılı kanun ve zorunlu kentleşme. Çağdaş Yerel Yönetimler Dergisi, 27(2), 1-44.

Visser, J. A. (2002). Understanding local government cooperation in urban regions: Toward a cultural model of interlocal relations. American Review of Public Administration, 32(1), 40-65. https://doi/pdf/10.1177/0275074002032001003

Wood, R. (1958). Metropolitan government, 1975: An extrapolation of trends: The New Metropolis:Greeenbelt, grass roots or Gargantua? American Political Science Review, 52, 108-122. 06.07.2020 tarihinde https://www.jstor.org/stable/pdf/1953016.pdf?. adresinden erişildi.

Yaşamış, F. D. (1995). Büyükşehir sorunsalı. Amme İdare Dergisi, 28 (1), 93-111.

Zimmermann U. (2007). Metropolitan governance. Department of Political Science and International Affairs, Kennesaw State University, Kennesaw, Georgia, U.S.A., https://doi:10.1081/E-EPAP-120041422

\section{Kaynakça Bilgisi / Citation Information}

Bimay, M. (2020). Mardin Büyükşehir Belediyesi örneğinde yeni büyükşehir belediye modeli uygulamasının yerel halka yansımaları. OPUS-Uluslararası Toplum Araştırmaları Dergisi, 16(Eğitim ve Toplum Özel Say1s1), 6215-6243. DOI: 10.26466/opus.823674 